\title{
Antioxidant Capacity and Biological Activity of Essential Oil and Methanol Extract of Conobea scoparioides (Cham. \& Schltdl.) Benth.
}

\author{
Monaliza M. Rebelo, ${ }^{a}$ Joyce Kelly R. da Silva ${ }^{b}$ Eloísa Helena A. Andrade ${ }^{c}$ and José Guilherme S. Maia*,c \\ ${ }^{a}$ Programa de Pós-Graduação em Ciências e Tecnologia de Alimentos and ${ }^{c}$ Faculdade de Engenharia Química, \\ ${ }^{b}$ Programa de Pós-Graduação em Química, Universidade Federal do Pará, 66075-900 Belém-PA, Brazil
}

\begin{abstract}
Os óleos essenciais da planta sub-aquática Conobea scoparioides (fresca e previamente seca) apresentaram rendimentos de 3,4 e 3,3\%, respectivamente. Os principais constituintes identificados foram o éter metílico do timol (39,6 e 47,7\%), timol (40,0 e 26,4\%), $\alpha$-felandreno (12,1 e 14,3\%) e p-cimeno (1,5 e 1,7\%), totalizando mais de $90 \%$ nos referidos óleos. A concentração de seqüestro do radical DPPH $\left(\mathrm{CE}_{50}\right)$ dos óleos e extrato foi de $46,7 \pm 3,6 \mu \mathrm{g} \mathrm{mL} \mathrm{L}^{-1}$ para a planta fresca (CsO-f), de 56,1 $\pm 2,4 \mu \mathrm{g} \mathrm{mL} \mathrm{L}^{-1}$ para a planta seca (CsO-d), e de 23,0 $\pm 2,2 \mu \mathrm{g} \mathrm{mL} \mathrm{m}^{-1}$ para o extrato metanólico (CsE-d). O valor do extrato é comparável ao BHT $\left(19,8 \pm 0,5 \mu \mathrm{g} \mathrm{mL}^{-1}\right)$, usado como padrão antioxidante. $\mathrm{O}$ valor médio dos óleos é duas vezes menor, mas igualmente importante como agente antioxidante. O teor de Fenólicos Totais (TP, 124,6 \pm 8,7 mg GAE per g) e o Trolox Equivalente (TEAC, 144,1 \pm 4,9 mg TE per g) do extrato metanólico confirmaram a significativa atividade antioxidante de $C$. scoparioides. Da mesma forma, nos bioensaios com larva de camarão (Artemia salina) o valor médio da concentração letal dos óleos $\left(\mathrm{CL}_{50}, 7,7 \pm 0,3 \mu \mathrm{g} \mathrm{mL^{-1 }}\right)$ foi dez vezes maior que no extrato metanólico $\left(\mathrm{CL}_{50}, 77,6 \pm 7,1 \mu \mathrm{g} \mathrm{mL} \mathrm{m}^{-1}\right)$ mostrando importante atividade biológica.
\end{abstract}

The essential oils of the sub-aquatic plant Conobea scoparioides (fresh and dried previously) showed yields of 3.4 and $3.3 \%$, respectively. The main identified constituents were thymol methyl ether (39.6 and 47.7\%), thymol (40.0 and 26.4\%), $\alpha$-phellandrene (12.1 and $14.3 \%$ ) and $p$-cymene ( 1.5 and $1.7 \%$ ), totalizing more than $90 \%$ of the oils. The DPPH radical scavenging activity $\left(\mathrm{EC}_{50}\right)$ of the oils and extract was $46.7 \pm 3.6 \mu \mathrm{g} \mathrm{mL}^{-1}$ in the fresh plant (CsO-f), $56.1 \pm 2.4 \mu \mathrm{g} \mathrm{mL}^{-1}$ in the dried plant (CsO-d), and 23.0 $\pm 2.2 \mu \mathrm{g} \mathrm{mL}^{-1}$ in the methanol extract. The extract (CsE-d)value is comparable to BHT $\left(19.8 \pm 0.5 \mu \mathrm{g} \mathrm{mL}^{-1}\right)$ used as antioxidant standard. The mean value of the oils is twice smaller but equally important as antioxidant agent. The mean amount of Total Phenolics (TP, 124.6 $\pm 8.7 \mathrm{mg}$ GAE per $\mathrm{g}$ ) and the Trolox Equivalent (TEAC, $144.1 \pm 4.9 \mathrm{mg}$ TE per $\mathrm{g}$ ) of the methanol extract confirmed the significant antioxidant activity of $C$. scoparioides. Similarly, in the brine shrimp bioassay (Artemia salina) the mean value of the lethal concentration for the oils $\left(\mathrm{LC}_{50}, 7.7 \pm 0.3 \mu \mathrm{g} \mathrm{mL}^{-1}\right)$ was ten times higher than the methanol extract $\left(\mathrm{LC}_{50}, 77.6 \pm 7.1 \mu \mathrm{g} \mathrm{mL}^{-1}\right)$ showing important biological activity.

Keywords: Conobea scoparioides, Scrophulariaceae, pataqueira, thymol and thymol methyl ether, antioxidant capacity, cytotoxicity

\section{Introduction}

The Scrophulariaceae is a cosmopolitan family comprising nearly 400 genera and 4,500 species, with their dispersion centre in the temperate regions of the north hemisphere. There are few species occurring in the Amazon. The species Conobea scoparioides (Cham. \& Schltdl.) Benth. (syn. Sphaerotheca scoparioides Cham. \& Schldtl.)

*e-mail: gmaia@ufpa.br is a native erect herb called "pataqueira" or "vassourinhado-brejo", growing wild in seasonally inundated areas, with opposite leaves, sometimes alternate, deltoid, ovalate or lanceolate, with serrate or crenate margins. The whole plant is used for aromatic baths on the St John annual festivity and to treat "beri-beri" (a disease provoked by lack of vitamin $B_{1}$ ) by the Amazon native people. ${ }^{1}$ Previously, the main volatiles identified in the essential oils of $C$. scoparioides were thymol, methyl thymol, $\alpha$-phellandrene and $p$-cymene. ${ }^{2,3}$ The plant extract and the compound curcubitacin E isolated 
from were identified as cell-adhesion inhibitors. ${ }^{4}$ Another plant extract of $C$. scoparioides occurring in Colombia showed leishmanicidal activity at same range of glucantime control. ${ }^{5}$

As part of an ongoing inventory of the Amazon aromatic plants this paper reports the essential oil composition of one sample of Conobea scoparioides, as well as the antioxidant capacity and the biological activity of the plant oils and methanol extract using the DPPH radical scavenging and the brine shrimp bioassay, respectively.

\section{Experimental}

\section{Plant material}

The specimen of $C$. scoparioides was collected in the experimental area of Embrapa, Municipality of Belém, Pará State, Brazil, in August 2005. The plant was identified by comparison with an authentic voucher of Conobea scoparioides (\#MG174901) that is deposited in the herbarium of Emílio Goeldi Museum, city of Belém, Pará State, Brazil.

\section{Plant processing}

The plant material was divided in fresh and air-dried portions $(150 \mathrm{~g}$, each) and submitted to hydrodistillation using a Clevenger-type apparatus $(3 \mathrm{~h})$. The hydrodistilled oils were dried over anhydrous sodium sulfate and the yield calculated on basis of the plant dry weight. The moisture content of the samples was calculated after the phase separation in a Dean-Stark trap (5 g, 30 min) using toluene. The powdered air-dried sample was submitted to solvent extraction (75 g, $4 \mathrm{~h})$ using Sohxlet extractor and methanol. The methanol extract was submitted to vacuum evaporation to eliminate the solvent and the yield was calculated. The oils were codified as $\mathrm{CsO}-\mathrm{f}$ and $\mathrm{CsE}-\mathrm{d}$ for fresh and dried samples. The methanol extract was codified as CsE-d.

\section{Oil composition analysis}

The qualitative analysis of the volatile compounds was performed on a Finnigan Mat INCOS XL GC-MS instrument, with the following conditions: WCOT DB-5ms (30 $\mathrm{m} \times 0.25 \mathrm{~mm} ; 0.25 \mu \mathrm{m}$ film thickness) fused silica capillary column; temperature programmed: $60-240{ }^{\circ} \mathrm{C}$ $\left(3{ }^{\circ} \mathrm{C} \mathrm{min}^{-1}\right)$; injector temperature: $220{ }^{\circ} \mathrm{C}$; carrier gas: helium, adjusted to a linear velocity of $32 \mathrm{~cm} \mathrm{~s}^{-1}$ (measured at $100{ }^{\circ} \mathrm{C}$ ); injection types: (i) the SPME device coupled directly to GC injector and (ii) splitless $(2 \mu \mathrm{L}$, of a 1:1000 hexane solution); split flow was adjusted to give a 20:1 ratio; septum sweep was a constant $10 \mathrm{~mL} \mathrm{~min}^{-1}$; EIMS: electron energy, $70 \mathrm{eV}$; ion source temperature and connection parts: $180{ }^{\circ} \mathrm{C}$. The quantitative data of oils and SPME concentrates were obtained by peak area normalization using a HP 5890 GC/FID operated under the same GC-MS conditions, except for the carrier gas that was hydrogen produced by a Packard hydrogen generator and a WCOT CP-Sil CB $(25 \mathrm{~m} \times 0.25 \mathrm{~mm} ; 0.25 \mu \mathrm{m}$ film thickness) fused silica capillary column. Individual components of oils were identified by comparison of both mass spectrum and their GC retention data with those of authentic compounds previously analyzed and stored in the data system. Additional identifications were made by comparison of mass spectra with those existing in the data system libraries and cited in the literature. ${ }^{6}$ The retention index was calculated for all volatile constituents using an $n$-alkanes homologous series.

\section{Antioxidant capacity evaluation}

A stock solution of DPPH radical $\left(0.5 \mathrm{mmol} \mathrm{L}^{-1}\right)$ in methanol was prepared. The solution was diluted in methanol $\left(c a .60 \mu \mathrm{mol} \mathrm{L}^{-1}\right)$, measuring an initial absorbance of $0.62 \pm 0.02 \mathrm{in} 517 \mathrm{~nm}$, at room temperature. The reaction mixture was composed by $1950 \mu \mathrm{L}$ of DPPH solution and $50 \mu \mathrm{L}$ of the samples diluted in different methanol portions. For each sample a methanol blank was also measured. The absorbance was measured in the reaction start (time zero), every $5 \mathrm{~min}$ during the first $20 \mathrm{~min}$ and then at continuous intervals of 10 min up to constant absorbance. All experiments were triplicate. Trolox (6-hydroxy-2,5,7,8tetramethylchroman-2-carboxylic acid) and BHT (butylated hydroxytoluene) were used as standard antioxidants. The radical scavenging activity of each sample was calculated by the DPPH inhibition percentage according the equation 1 ,

$\mathrm{IP}_{\mathrm{DPPH}}=100(\mathrm{~A}-\mathrm{B}) / \mathrm{A}$

where A and B are the blank and sample absorbance values in the reaction end. The radical scavenging activity, expressed as milligrams of trolox equivalent per gram of each sample, was also calculated by means of the equation 2 ,

$\mathrm{TE}=(\mathrm{A}-\mathrm{B}) /(\mathrm{A}-\mathrm{C}) \times 25 / 1000 \times 250.29 / 1000 \times 1000 / 10 \times \mathrm{D}$

where $\mathrm{A}, \mathrm{B}$ and $\mathrm{C}$ are the blank, sample and trolox absorbance values in the reaction end, and $\mathrm{D}$ is the dilution factor. ${ }^{7-9}$ The concentration of antioxidant required for $50 \%$ scavenging of DPPH radicals $\left(\mathrm{EC}_{50}\right)$ was determined by linear regression using Windows/Excel. 


\section{Total phenolics evaluation}

The amount of total phenolics (TP) of plant extract was determined according to the Folin-Ciocalteu procedure. ${ }^{10,11}$ The experimental calibration curve was prepared using $500 \mu \mathrm{L}$ of aqueous solution of gallic acid mixed with $250 \mu \mathrm{L}$ of Folin-Ciocalteu reagent $\left(1 \mathrm{~mol} \mathrm{~L}^{-1}\right)$ and $1250 \mu \mathrm{L}$ of sodium carbonate $\left(75 \mathrm{~g} \mathrm{~L}^{-1}\right)$ resulting in final gallic acid concentrations of $0.57,1.14,2.28,3.42,4.56,5.70$ and $6.84 \mathrm{mg} \mathrm{L}^{-1}$. The absorbance was measured after $30 \mathrm{~min}$ at $760 \mathrm{~nm}$ and $25^{\circ} \mathrm{C}$ (UV-Vis spectrophotometer, ULTROSPEC 2000). The extract was dissolved in methanol ( $\left.2 \mathrm{mg} \mathrm{mL}^{-1}\right)$, diluted in water (1:99) and submitted to the same procedure. The total phenolics content was expressed as gallic acid equivalents (GAE) in milligrams per gram of extract, using the equation 3 ,

$\operatorname{GAE}\left(\mathrm{mg} \mathrm{L}^{-1}\right)=\mathrm{A} \times \mathrm{D} \times 7.93 \times \mathrm{d}$,

where $\mathrm{A}$ = sample absorbance; $\mathrm{D}$ = sample dilution; 7.93 = angular coefficient; $\mathrm{d}=$ reaction dilution .

\section{Brine shrimp bioassay}

Brine shrimp lethality bioassay was carried out to investigate the cytotoxicity (biological activity) of the oils and extract. ${ }^{12,13}$ Brine shrimps (Artemia salina) were hatched using brine shrimp eggs in a glass rectangular vessel $(5 \mathrm{~L})$, filled with sterile artificial seawater, prepared using water (2 L), $\mathrm{NaCl}(46 \mathrm{~g}), \mathrm{MgCl}_{2} \cdot 6 \mathrm{H}_{2} \mathrm{O}(22 \mathrm{~g})$, $\mathrm{Na}_{2} \mathrm{SO}_{4}(8 \mathrm{~g}), \mathrm{CaCl}_{2} \cdot 2 \mathrm{H}_{2} \mathrm{O}(2.6 \mathrm{~g})$ and $\mathrm{KCl}(1.4 \mathrm{~g})$, with pH 9.0 adjusted with $\mathrm{Na}_{2} \mathrm{CO}_{3}$, under constant aeration for $48 \mathrm{~h}$. After hatching, active nauplii free from egg shells were collected from brighter portion of the hatching chamber and used for the assay. Ten nauplii were drawn through a glass capillary and placed in vials containing $5 \mathrm{~mL}$ of brine solution. In each experiment the oil $(1 \%)$ and extract $(5 \%)$ solutions were prepared using the brine solution and DMSO. From them four other solutions at different concentrations were prepared and then added to the $5 \mathrm{~mL}$ brine solution. The vials were maintained at room temperature for $24 \mathrm{~h}$ under the light and the surviving larvae were counted. Experiments were conducted along with control and different concentrations $\left(1,10,100\right.$ and $\left.1000 \mu \mathrm{g} \mathrm{mL} \mathrm{m}^{-1}\right)$ in a set of three tubes per dose. The percentage lethality was determined by comparing the mean value of surviving larvae of the test and the control tubes. Lethal concentration $\left(\mathrm{LC}_{50}\right)$ values were obtained from the best-fit line plotting concentration versus percentage lethality. ${ }^{14}$

\section{Results and Discussion}

The oil yields for fresh (CsO-f) and dried (CsO-d) plants of C. scoparioides were $3.4 \%$ and $3.3 \%$, respectively, and were shown to be higher than those previously reported, ${ }^{2,3}$ while the oils chemical composition seems like similar to former analysis in which thymol methyl ether (CsO-f, $39.6 \%$, CsO-d, $47.7 \%$ ), thymol (CsO-f, $40.0 \%$, CsO-d, $26.4 \%$ ), $\alpha$-phellandrene (CsO-f, $12.1 \%, \mathrm{CsO}-\mathrm{d}, 14.3 \%$ ) and $p$-cymene (CsO-f, $1.5 \%, \mathrm{CsO}-\mathrm{d}, 1.7 \%$ ) were the main constituents, totalizing over $90 \%$. In the fresh plant oil the percentage values of thymol and thymol methyl ether are similar while for the dried plant oil the percentage value of methyl thymol ether is two times higher than the thymol. For these differences we are assuming that the enzymatic action for thymol methylation might be accelerated by the drying process. Similarly, the higher oil yields for this $C$. scoparioides sample might be explained by the environmental aspects of the plant collection site in comparison to previous analyses. ${ }^{2,3}$ The volatiles identified in the plant oils are listed in Table 1.

Table 1. Composition of volatiles identified in the oils of C. scoparioides

\begin{tabular}{|c|c|c|c|c|}
\hline No. & Components & $R I^{\mathrm{a}}$ & $\mathrm{CsO}-\mathrm{f} /(\%)^{\mathrm{b}}$ & $\mathrm{CsO}-\mathrm{d} /(\%)^{\mathrm{b}}$ \\
\hline 1 & $\alpha$-thujene & 930 & 0.2 & 0.3 \\
\hline 2 & sabinene & 975 & 0.2 & - \\
\hline 3 & $\beta$-pinene & 979 & 0.3 & 0.2 \\
\hline 5 & $\alpha$-phellandrene & 1003 & 12.1 & 14.3 \\
\hline 6 & $p$-cymene & 1025 & 1.5 & 1.7 \\
\hline 7 & limonene & 1028 & 0.1 & 0.1 \\
\hline 8 & $\beta$-phellandrene & 1030 & 0.2 & 0.2 \\
\hline 9 & $(E)$ - $\beta$-ocimene & 1050 & 0.5 & 0.7 \\
\hline 10 & $\gamma$-terpinene & 1060 & 0.4 & 0.3 \\
\hline 11 & linalool & 1097 & 0.2 & 0.2 \\
\hline 12 & $p$-cimen-8-ol & 1188 & 0.4 & 0.7 \\
\hline 13 & thymol methyl ether & 1235 & 39.6 & 47.7 \\
\hline 14 & thymol & 1290 & 40.0 & 26.4 \\
\hline 15 & eugenol & 1360 & 0.2 & 0.2 \\
\hline 16 & Viridiflorene & 1496 & 0.5 & 1.2 \\
\hline 17 & $\alpha$-selinene & 1498 & 0.2 & 0.9 \\
\hline \multirow[t]{2}{*}{18} & $(E, E)$ - $\alpha$-farnesene & 1508 & 1.2 & 1.3 \\
\hline & $\begin{array}{l}\text { Sesquiterpenes not } \\
\text { identified }^{c}\end{array}$ & & 0.4 & 1.4 \\
\hline Tota & & & 99.7 & 99.6 \\
\hline
\end{tabular}

a Retention indices calculated for all volatile constituents using a homologous series of $n$-alkanes. ${ }^{b}$ Percentages are the mean of three runs and were obtained from FID electronic integration. ${ }^{\mathrm{c}} \mathrm{MW}=220$ and 222 . 
Table 2. Antioxidant capacity data of the plant oils and extract of $C$. scoparioides

\begin{tabular}{|c|c|c|c|c|c|}
\hline Samples & $\begin{array}{c}\text { Concentration / } \\
\left(\mu \mathrm{g} \mathrm{mL} L^{-1}\right)\end{array}$ & DPPH Inhibition ${ }^{\mathrm{a}}$ (\%) & $\begin{array}{c}\mathrm{DPPH} \mathrm{EC}{ }_{50}{ }^{\mathrm{a}} / \\
\left(\mu \mathrm{g} \mathrm{mL}^{-1}\right)\end{array}$ & $\begin{array}{c}\text { TEAC }^{\text {a }} \\
(\text { mg TE per } \mathrm{g})\end{array}$ & $\begin{array}{c}\text { ТРa / } \\
\text { (mg GAE per } \mathrm{g})\end{array}$ \\
\hline \multirow[t]{5}{*}{$\mathrm{CsO}-\mathrm{f}$} & 186.5 & $82.0 \pm 1.6$ & & & \\
\hline & 93.3 & $69.3 \pm 0.9$ & & & \\
\hline & 46.6 & $53.6 \pm 0.9$ & $46.7 \pm 3.6$ & $72.3 \pm 1.3$ & - \\
\hline & 23.3 & $43.1 \pm 0.7$ & & & \\
\hline & 11.6 & $34.7 \pm 0.6$ & & & \\
\hline \multirow[t]{5}{*}{$\mathrm{CsO}-\mathrm{d}$} & 186.5 & $80.3 \pm 1.7$ & & & \\
\hline & 93.3 & $64.7 \pm 0.8$ & & & - \\
\hline & 46.6 & $51.3 \pm 1.6$ & $56.1 \pm 2.4$ & $67.5 \pm 1.2$ & \\
\hline & 23.3 & $41.0 \pm 0.9$ & & & \\
\hline & 11.6 & $32.8 \pm 0.72$ & & & \\
\hline \multirow[t]{5}{*}{ CsE-d } & 100.0 & $94.0 \pm 0.2$ & & & \\
\hline & 57.0 & $80.9 \pm 1.6$ & & & \\
\hline & 40.0 & $59.7 \pm 1.4$ & $23.0 \pm 2.2$ & $144.1 \pm 4.9$ & $124.6 \pm 8.7$ \\
\hline & 20.0 & $47.8 \pm 0.7$ & & & \\
\hline & 10.0 & $38.2 \pm 0.7$ & & & \\
\hline \multirow[t]{3}{*}{ Trolox } & 10 & $96.7 \pm 0.5$ & & & \\
\hline & 4 & $53.2 \pm 1.6$ & $4.7 \pm 0.4$ & - & - \\
\hline & 2 & $21.5 \pm 2.3$ & & & \\
\hline $\mathrm{BHT}^{\mathrm{b}}$ & - & - & $19.8 \pm 0.5$ & - & - \\
\hline
\end{tabular}

${ }^{\mathrm{a}}$ Mean \pm standard deviation. ${ }^{\mathrm{b}}$ Literature data.

The sample oils of $C$. scoparioides ( $\mathrm{CsO}-\mathrm{f}$ and $\mathrm{CsO}-\mathrm{d}$ ) were assayed at 11.6, 23.3, 46.6, 93.3 and $186.5 \mu \mathrm{g} \mathrm{mL}$ to determine the DPPH scavenging activity. The kinetic reaction was slow in all concentrations with a mean of $180 \mathrm{~min}$ for the mentioned sample oils. The DPPH inhibition ranged from percent varied from 34.7 to $82.1 \%$ in the fresh sample oil (CsO-f) and from 32.8 to $80.3 \%$ in the air-dried sample oil (CsO-d) showing similar properties. The plant extract of $C$. scoparoides (CsE-d) was assayed at concentration from 10.0 to $100.0 \mu \mathrm{g} \mathrm{mL}^{-1}$ to determine the DPPH scavenging activity. The reaction kinetic was slow in all tested concentrations with a mean of $120 \mathrm{~min}$ for the mentioned plant extract. The resulting DPPH inhibition percent varied from 38.2 to $94.0 \%$ in the plant extract (CsE-d).

The $\mathrm{EC}_{50}$ values obtained for the $C$. scoparioides plant oils (CsO-f: $46.7 \pm 3.6 \mu \mathrm{g} \mathrm{mL}^{-1}$; CsO-d: $56.1 \pm 2.4 \mu \mathrm{g} \mathrm{mL}^{-1}$ ), defined as the concentration of antioxidant required for $50 \%$ scavenging of DPPH radicals, are two times higher that of butylated hydroxytoluene (BHT: $19.8 \pm 0.5 \mu \mathrm{g} \mathrm{mL}^{-1}$ ), ${ }^{15}$ but as active as this commercial antioxidant, signifying that the species essential oil has important antioxidative capacity. Similarly, the $\mathrm{EC}_{50}$ of the plant extract (CsE-d: $\left.23.0 \pm 2.2 \mu \mathrm{g} \mathrm{mL}^{-1}\right)$ can be comparable to trolox $(4.7 \pm$ $\left.0.4 \mu \mathrm{g} \mathrm{mL}^{-1}\right)$ in absolute values, therefore having a high antioxidant activity. Probably, the higher antioxidant effect of the plant extract is due the presence of other phenolic compounds in the plant extract.

The amount of total phenolics (CsE-d: $124.6 \pm 8.7 \mathrm{mg}$ GAE per g) and the TEAC equivalent (CsE-d: $144.1 \pm$ $4.9 \mathrm{mg}$ TE per $\mathrm{g}$ ) for the methanol extract were significant and could be attributed to the presence of polar phenolics in a synergistic effect with the high content of thymol and its methyl ether identified in the plant oils. Oregano essential oils rich on thymol and carvacrol have shown considerable antioxidant activity on the process of food oxidation. ${ }^{16,17}$

The data of DPPH inhibition, DPPH radical activity $\left(\mathrm{EC}_{50}\right)$, trolox equivalent antioxidant capacity (TEAC) and total phenolics (TP) for the plant oils (CsO-f and CsO-d) and methanol extract (CsE-d) of C. scoparioides are shown in Table 2.

For the brine shrimp bioassay performed with the plant oils (CsO-f and $\mathrm{CsO}-\mathrm{d})$ the lethal concentrations $\left(\mathrm{LC}_{50}\right)$ were $7.8 \pm 0.3 \mu \mathrm{g} \mathrm{mL} L^{-1}$ and $7.5 \pm 0.3 \mu \mathrm{g} \mathrm{mL}^{-1}$, respectively, showing a high cytotoxicity. On the other hand, for the plant extract (CsE-d) the value was $77.6 \pm 7.1 \mu \mathrm{g} \mathrm{mL}^{-1}$ signifying a citotoxicity ten times lower. Oils and extracts from plants presenting $\mathrm{LC}_{50}$ values below $1000 \mu \mathrm{g} \mathrm{mL}^{-1}$ are considered as bioactive..$^{18}$ In the case of $C$. scoparioides the plant oils (CsO-f and $\mathrm{CsO}-\mathrm{d}$ ) presented higher biological activity than 
Table 3. Lethal concentration $\left(\mathrm{LC}_{50}\right)$ of the plant oil and methanol extract of $C$. scoparioides for the brine shrimp bioassay

\begin{tabular}{lccc}
\hline Samples & $\begin{array}{c}\text { Concentration / } \\
\left(\mu \mathrm{g} \mathrm{mL}^{-1}\right)\end{array}$ & $\begin{array}{c}\text { Mortality / } \\
(\%)\end{array}$ & $\begin{array}{c}\mathrm{CL}_{50} / \\
\left(\mu \mathrm{gL}^{-1}\right)\end{array}$ \\
\hline CsO-f & 1 & 0 & $7.8 \pm 0.3$ \\
& 5 & 5.0 & \\
CsO-d & 10 & 52.9 & $7.5 \pm 0.3$ \\
& 1 & 100.0 & \\
& 5 & 0 & \\
& 10 & 13.0 & \\
& 25 & 53.6 & \\
& 1 & 100.0 & \\
& 25 & 0 & \\
& 50 & 10.0 & \\
& 500 & 40.0 & \\
& & 100.0 & \\
\hline
\end{tabular}

the plant extract (CsE-d). Data for brine shrimp bioassay is shown in Table 3.

\section{Acknowledgments}

The authors are grateful to Biodiversity Program (PPBio), Ministry of Science and Technology (MCT/ $\mathrm{CNPq}$ ), Brazilian Government, for financial support.

\section{References}

1. Maia, J. G. S.; Zoghbi, M. G. B.; Andrade, E. H. A; Plantas Aromáticas da Amazônia e Seus Óleos Essenciais; Museu Paraense Emílio Goeldi: Belém, Brasil, 2001.

2. de Morais, A. A.; Mourão, J. C.; Gottlieb, O. R.; da Silva, M. L.; Marx, M. C.; Maia, J. G. S., Magalhães, M. T.; Acta Amaz. 1972, 2, 45.

3. Maia, J. G. S.; Zoghbi, M. G. B.; Andrade, E. H. A.; Silva, M. H. L.; Flavour Fragr. J. 2000, 15, 413.
4. Musza, L. L.; Speight, P.; McElhiney, S.; Barrow, C. J.; Gillum, A. M.; Cooper, R.; Killar, L. M.; J. Nat. Prod. 1994, 57, 1498.

5. Weniger, B.; Robledo, S.; Arango, G. J.; Deharo, E.; Aragon, R.; Munoz, V.; Callapa, J.; Lobstein, A.; Anton, R.; J. Ethnopharmacol. 2001, 78, 193.

6. Adams, R. P.; Identification of Essential Oil Components by Gas Chromatography Quadrupole Mass Spectroscopy; Allured: Carol Stream, Illinois, USA, 2001.

7. Choi, H. S.; Song, H. S.; Ukeda, H.; Sawamura, M.; J. Agric. Food Chem. 2000, 48, 4156.

8. Hu, Q.; Xu, J.; Chen, S.; Yang, F.; J. Agric. Food Chem. 2004, 52, 9439.

9. Yamaguchi, T.; Takamura, H.; Matoba, T.; Terao, J.; Biosci., Biotechnol., Biochem. 1998, 62, 1201.

10. Singleton, V. L.; Rossi, J. A.; Am. J. Enol. Vitic. 1965, 16, 144.

11. Kähkönen, M.P.; Hopia, A. I.; Vuorela, H. J.; Rauha, J. P.; Pihlaja, K.; Kujala, T. S.; Heinonen, M.; J. Agric. Food Chem. 1999, 47, 3954.

12. Meyer, B. N.; Ferrigni, N. R.; Putnam, J. E.; Jacobsen, L. B.; Nichols, D. E.; McLaughlin, J. L.; Planta Med. 1982, 45, 31.

13. Lewan, L.; Anderson, M.; Morales-Gomez, P.; Alternatives to Laboratory Animals 1992, 20, 297.

14. Finney, D. J.; Probits Analysis; Cambridge University Press: Cambridge, 1971.

15. Sökmen, M.; Serkedjieva, J.; Daferera, D.; Gulluece, M.; Polissiou, M.; Tepe, B.; Akpulat, A.; Sahin, F.; Sökmen, A.; J. Agric. Food Chem. 2004, 52, 3309.

16. Lagouri, V.; Blekas, G.; Tsimidou, M.; Kokkini, S.; Boskou, D.; Z. Lebensmitt.-Unters. Forsch. 1993, 197, 20.

17. Milos, M.; Mastelic, J.; Jerkovic, I.; Food Chem. 2000, 71, 79.

18. Meyer, B. N.; Ferrigni, N. R.; Putnam, J. E.; Jacobsen, L. B.; Nichols, D. E.; McLaughlin, J. L.; Planta Med. 1982, 45, 31.

Received: January 6, 2008 Web Release Date: March 20, 2009 